\title{
Potencjał badawczy kategorii kognitywistycznych. W poszukiwaniu nowej formuły dyskursu edukacyjnego
}

\section{KEYWORDS}

the discourse of a textbook, the discourse of children, the cognitive science, the language image of the world, the text image of the world, point of view and perspective, type of rationality, method of categorizing, stereotypical and axiological overview of the reality

\begin{abstract}
Wiśniewska-Kin Monika, Potencjał badawczy kategorii kognitywistycznych. W poszukiwaniu nowej formuły dyskursu edukacyjnego [Cognitive categories as inspiration for research. In search for new formula of educational discourse]. Kultura Społeczeństwo - Edukacja nr 2(12) 2017, Poznań 2017, pp. 173-184, Adam Mickiewicz University Press. ISSN 2300-0422. DOI 10.14746/kse.2017.12.8.
\end{abstract}

In order to describe in detail the differences between the discourse of a textbook and the discourse of children I used categories - applied in the area of cognitive considerations - concerning the language image of the world and the text image of the world, as well as selected sub-categories: point of view and perspective, type of rationality, method of categorizing, stereotypical and axiological overview of the reality.

I assumed that the choice of categories and subcategories will not only allow to investigate the imposed meanings of the textbook discourse, but - above all - will make it possible to notice the very process of formation, the emergence of the image of the world from the perspective of children. The adopted analysis model launches reflection on the necessary changes, exposes the oppressiveness of the language of the textbook and encourages exploring the conditions to initiate the language of children.

Rozważania ujęte $\mathrm{w}$ artykule zogniskuję wokół wątków stwarzających dogodny klimat do zainicjowanego przez Marię Dudzikową, Adama Chmielewskiego i Adama Groblera myślenia o interdyscyplinarnym kontekście badań edukacyj- 
nych (Chmielewski, Dudzikowa, Grobler, 2012). Rozważania te są ważne z wielu powodów. Dla mnie najistotniejsze są trzy:

- stwarzają możliwość stawiania pytań o źródła stagnacji szkoły z różnych perspektyw;

- uruchamiają rozległą przestrzeń do myślenia o koniecznych zmianach;

- tworzą podwaliny innego podejścia do dyskursu edukacyjnego.

Zaproponowany kontekst teoretyczny stwarza badaczom możliwość określenia na nowo zamierzeń szkoły i dokonania wszechstronnej rewizji wszystkich jej obszarów działania. Zasadność oddziaływań dzisiejszej edukacji pozwala skonfrontować z realnymi wyzwaniami współczesności i przewidywanymi kierunkami jej przeobrażeń. Przyjrzyjmy się bliżej tym wątkom.

\section{Kognitywizm jako kontekst badań edukacyjnych}

W obszarze badań pedagogicznych nowym, inspirującym kontekstem teoriopoznawczym może być kognitywizm. Jako dziedzina badająca procesy poznawcze ma charakter interdyscyplinarny; sytuuje się pomiędzy filozofią (epistemologią), psychologią, językoznawstwem, antropologią i neurologią, a nawet cybernetyką czy robotyką (por. Wierzchoń, Orzechowski, Barbasz, 2012: 114). Wspólną przestrzeń stanowi odniesienie do poznania, a ściślej: myślenia, zainteresowania procesami poznawczymi, nabywaniem wiedzy, szerzej - uczeniem się.

Przedmiotem rozważań teoretycznych kognitywizm czyni całą złożoność i wielowymiarowość rzeczywistości, stawiając pytania o naturę ludzkiego umysłu poznającego rzeczywistość, którą nauki przyrodnicze pozbawiły stałych punktów odniesienia i złudzeń, że świat da się zamknąć w mechanistycznej koncepcji i ująć w zestawie twierdzeń obiektywnych, pewnych.

Kognitywizm zmienił też status języka. Przestaje on być postrzegany jako obiektywna struktura $\mathrm{z}$ systemem reguł gramatycznych, $\mathrm{z}$ wbudowanymi mechanizmami ich stosowania, umożliwiającymi tworzenie zrozumiałych wypowiedzi. Przyjmuje się, że struktura języka jest determinowana przez schematy aktywacji neuronowej, będące częścią całościowej aktywności mózgu i ciała. Procesy poznawcze mają jednak w znacznym stopniu charakter indywidualny. Znaczenia zaś składają się z treści pojęciowej, wyrażającej konkretne aspekty otaczającego nas świata nie w sposób bezpośredni; tkwią w operacjach myślowych lub w ogólnych sposobach widzenia świata, przesączonych jednak przez osobiste, niepowtarzalne postrzeganie i ujmowanie tego, w czym zanurzone jest poznające indywiduum ${ }^{1}$.

${ }^{1}$ Wykład Pierwszych 40 lat, wygłoszony przez Ronalda Langackera z okazji przyznania mu tytułu doktora honoris causa Uniwersytetu Łódzkiego w dniu 1 października 2003 roku. 
Kognitywizm otwiera więc całkiem nowe przestrzenie i dostarcza odkrywczych ujęć dla wszelkiej refleksji o edukacji. Poszukując odpowiedzi na podstawowe pytanie o to, jak to się dzieje, że się uczymy, w jaki sposób poznajemy, rozumiemy i ujmujemy świat, każe inaczej spojrzeć na możliwości poznawcze dzieci (por. Erlauer, 2003; Sprenger, 2003; Gupta, Richardson, 2001; Dąbrowska, Kubiński, 2003; Ożdżyński, 1995).

Zwraca uwage przede wszystkim na procesualny charakter uczenia się - stopniowe, subiektywne otwieranie się znaczeń w wyniku indywidualnie doświadczanego - przeprowadzanego na różne sposoby - kategoryzowania, profilowania i wartościowania. Uczenie się nie ma więc charakteru mechanicznego, a wiedza nie ma postaci gotowej, skończonej.

Zasadnicza zmiana wprowadzona w teorii procesów poznawczych przez kognitywizm zaowocowała więc koncepcją edukacji, której sednem jest tworzenie w procesie konstruowania wiedzy subiektywnych sposobów opisywania rzeczywistości, odkrywania, interpretowania i uzgadniania sensu, rozwijania postaw poszukujących, badawczych, samodzielności poznawczej. W tej koncepcji nie mieści się już przeświadczenie, że edukacja szkolna polega na przyswajaniu wiedzy gotowej, do czego wystarczy sprawny nauczyciel i dobry podręcznik. Odpowiedzi na pytania o to, jak, czego i po co uczyć, nie można już szukać w wąskim, wyłącznie racjonalistycznym paradygmacie przyrodniczym ani w strukturalistycznym ujęciu związków między językiem (mową) a myśleniem. Badania procesów poznawczych i funkcji języka w uczeniu się nie należą już tylko do sfery nauk przyrodniczych kognitywizm przesuwa je w sferę psychologiczną.

„Otwarcie” się na inne myślenie o procesie uczenia się wymaga jednak badawczej odwagi i czujności w uruchamianiu namysłu wykraczającego poza ramy macierzystej dyscypliny, a także gotowości do podjęcia badawczego ryzyka. Ważna jest również świadomość tego, że bardzo łatwo wpaść w pułapkę interdyscyplinarnych pozorów, tracąc z pola widzenia wyjściowe założenie o konieczności stwarzania nowego pola badawczego (por. Wierzchoń, Orzechowski, Barbasz, 2012).

\section{W poszukiwaniu nowej formuły dyskursu edukacyjnego}

Mimo „swoistej instytucjonalizacji badań nad dyskursem w polskiej pedagogice” (Ostrowicka, 2014: 47-68) oraz skategoryzowania dyskursu jako zasadniczego pojęcia pozwalającego spojrzeć całościowo na sposoby, formy, procesy, a także skutki komunikacji społecznej (Czachur, Kulczyńska, Kumięga, 2016: 8-9), lektura do- 
tychczasowych diagnoz jednoznacznie dowodzi, że pozostaje ono nadal poza dydaktyczną refleksją nad nauczaniem i wiedzą szkolną (Klus-Stańska, 2010: 147). Analizy dyskursu edukacyjnego prowadzi się przede wszystkim w ramach socjologicznej analizy dyskursu (Grzymała-Kazłowska, 2004; Horolets, 2008; Pawliszek, Rancew-Sikora, 2012), psychologicznej analizy dyskursu (Shugar, 1995; Kurcz, Bobryk, 2001), lingwistyki pedagogicznej (Bernstein, 1990: 163) i edukacyjnej (Rittel, 1994a: b).

Warto zatem w obszarze badań pedagogicznych uruchomić refleksję nad dyskursem edukacyjnym, która okazuje się istotna z co najmniej dwóch powodów. Po pierwsze, dyskurs umożliwia odnajdywanie i formułowanie nowych problemów i zagadnień w naukach społecznych, stając się źródłem licznych badań i nowych interpretacji (Klus-Stańska, 2010: 145). Po drugie zaś, zainteresowanie dyskursem edukacyjnym może pomóc przełamać długotrwały impas w podejmowaniu istotnych przekształceń edukacyjnych.

Badacze posługujący się kategorią dyskursu edukacyjnego stają przed koniecznością zdefiniowania tej kategorii dla potrzeb swoich badań. Nadają mu szerokie lub wąskie znaczenie. $\mathrm{W}$ szerszym znaczeniu, rozumienie dyskursu edukacyjnego wykracza poza usytuowanie $\mathrm{w}$ ramach edukacji zinstytucjonalizowanej i rozpatrywane jest w szerokiej społecznej i poznawczej perspektywie jako „każda forma transmisji wiedzy z perspektywy eksperta do perspektywy nowicjusza" (Skudrzyk, Warchala, 2002: 279-280). Dyskurs odnosi się do znacznie bardziej rozległych obszarów, takich jak „zdarzenia społeczne, tekst kulturowy, władza, czy wręcz cała rzeczywistość społeczna, której znaczenia są nadawane w toku dyskursywnych praktyk” (Klus-Stańska, 2010: 145). Wyróżnia go (1) „interakcja nadawczo-odbiorcza typu specjalista - adept (z archetypowymi rolami nauczyciela i ucznia) oraz (2) funkcja edukacyjna, wynikająca ze specyficznego celu komunikacyjnego, który można określić jako dążenie jednej ze stron (nauczyciela) do spowodowania określonej zmiany osobowościowej u partnera interakcji” (Nocoń, 2011: 190).

Natomiast w znaczeniu węższym dyskurs pojmowany jest jako:

1) proces komunikacji między nauczycielem i uczniem podczas wszystkich szkolnych sytuacji komunikacyjnych, również tych, w których nie są realizowane funkcje edukacyjne (np. podczas przerw międzylekcyjnych) (Wojtczuk, 2002: 300);

2) strategie „przekazywania wiedzy w sytuacjach nauczania lub szeroko rozumianego procesu kształcenia; przekształca wówczas specjalistyczny dyskurs źródłowy tak, aby stał się zrozumiały dla niespecjalisty; charakteryzuje go interakcja nauczający-nauczany" (Labocha, 1996: 9-15); 
3) „wypowiedź o określonych regułach modelowych, w której uwzględnia się wymiar podmiotowy - aktorów dyskursu, oraz czynnościowy - procesy komunikacji” (Rittel, 1996: 31-40). Takie jego rozumienie wyrażane jest kilkoma synonimicznymi terminami - dyskurs edukacyjny, dydaktyczny, szkolny, lekcyjny.

W swoich rozważaniach przyjmuję szerokie rozumienie dyskursu edukacyjnego, który rozumiem jako sposób „artykułowania istniejących intersubiektywnie przekonań, wyobrażeń, ocen, norm, wartości wytworzonych w praktyce społecznej, a szerzej - jako zbiór praktyk komunikowania przeświadczeń, zakorzenionych w osobistym doświadczeniu i kontekście kulturowym, związanych z rozumieniem jakiegoś obszaru rzeczywistości” (Wiśniewska-Kin, 2013: 94). Przy czym w moim przekonaniu, sposoby badania wybranego dyskursu, podejmowane interpretacje rzeczywistości świadomościowej, same stają się dyskursem, rodzajem metadyskursu, który odzwierciedla nastawienie i przeświadczenia badaczy, wytwarza repertuar pojęć, terminów i narzędzi, styl pracy analitycznej (Krauz, Gajda, 2005; Kowalski, 2010: 17-27; Wodak: 2011: 11-48). Dyskurs edukacyjny postrzegany jest więc jako konsekwencja przekonań teoretycznych (metadyskurs) uzasadniających tę praktykę; obejmuje całokształt zdarzeń - osoby, miejsca, czas, cele i skutki oraz zrytualizowane i sformalizowane działania rozgrywające się w instytucjach edukacyjnych (Wiśniewska, 2005).

\section{Dyskurs podręcznikowy i dziecięcy z perspektywy kognitywistycznej}

Przyjęta przeze mnie strategia badawcza wpisuje się w nurt interpretatywnych badań kognitywistycznych. $Z$ tej perspektywy podjęłam próbę wskazania jednego z możliwych sposobów rozważania rzeczywistości, która konstytuuje się na przecięciu wiedzy publicznej, wystandaryzowanej i utwierdzonej w podręczniku, i wiedzy osobistej dziecka, zanurzonej w jego indywidualnym, nieustannie wzbogacanym doświadczeniu. Dzięki tej strategii badawczej wydobyłam różnice wynikające z przeciwstawnych koncepcji edukacji. Jedna przejawia się w sposobie modelowania wizji świata przez teksty podręcznikowe. Druga zapewnia miejsce dla procesu konstruowania znaczeń w językowym obrazie świata z perspektywy dzieci.

Głównym celem badań uczyniłam skonfrontowanie apriorycznie ustanowionego dyskursu podręcznikowego, który zrekonstruowałam, z wyzwalanym w inspirującym środowisku edukacyjnym dyskursem uczniowskim. Aby zestawić horyzont pojęciowy i aksjologiczny, które da się wyabstrahować z podręczników, 
z językowo-kulturowym obrazem świata wyłaniającym się z wypowiedzi dzieci, posłużyłam się wypracowanymi i stosowanymi w badaniach kognitywistycznych kategoriami tekstowego obrazu świata i językowego obrazu świata oraz wybranymi podkategoriami: punktu widzenia i perspektywy, typu racjonalności, sposobu kategoryzowania, stereotypowego i aksjologicznego oglądu rzeczywistości. Założyłam, że wybór kategorii i podkategorii nie tylko umożliwi zbadanie apriorycznie narzuconych znaczeń dyskursu podręcznikowego, ale przede wszystkim pozwoli dostrzec $\mathrm{w}$ inicjowanym dyskursie dziecięcym proces rozumienia pojęć $\mathrm{z}$ wybranych przestrzeni.

Tekstowy obraz świata (TOS) rekonstruowałam z dyskursu podręcznikowego $^{2}$. Zawartość tekstowego obrazu świata badałam w polach leksykalno-semantycznych, które wypełniałam znaczeniami pogrupowanymi w czterech modelach środowiskowych: mikrosystemowym, mezosystemowym, egzosystemowym, makrosystemowym. Modele środowiskowe stały się również rodzajem kierunkowskazów podczas rekonstruowania uaktywnionego w dyskursie dziecięcym językowego obrazu świata (JOS) ${ }^{3}$. Dziecięcy namysł nad egzystencjalnymi wymiarami ludzkiego bytu skupiał się wokół czterech przestrzeni semantycznych (DOM, JA I SZKOŁA, WŚRÓD LUDZI, ŚWIAT), uszczegółowionych w tematach problemach, wyzwalanych w warunkach urozmaiconego, inspirującego i pobudzającego rozwój środowiska edukacyjnego. Źródło problematyki, w której dominował wymiar egzystencjalny, aksjologiczny i metafizyczny, stanowiła grupa celowo dobranych tekstów literackich.

${ }^{2} \mathrm{~W}$ przypadku badań tekstowego obrazu świata podręczników przyjęłam, że celem będzie nie analiza konkretnych publikacji, ale szczegółowy opis obecnej w nich „pedagogicznej kultury znaczeń". Ze względu na to, że nowe dane nie przynosiły innych reprezentacji, analizie poddałam sześć korpusów podręczników (słownik tematyczno-frekwencyjny liczy około 600 stron maszynopisu), obowiązujących w roku szkolnym 2012/2013 (szczegółowy wykaz podręczników zamieszczam w pracy Wiśniewska-Kin, 2013. Ponownie badania przeprowadziłam w 2016 roku. Zależało mi na tym, aby nie tylko rozpoznać obszary znaczeniowe współcześnie obowiązującego podręcznika Nasz elementarz, ale jednocześnie skonfrontować horyzont pojęciowy i aksjologiczny elementarza z tekstowym obrazem świata wyłaniającym się z dotychczas obowiązujących przykładowych podręczników. Analiza porównawcza miała wykazać, w jakim zakresie dokonała się zmiana w konstruowaniu podręcznikowego obrazu świata.

${ }^{3}$ Aby zidentyfikować znaczenia trzecioklasistów powszechnej szkoły podstawowej, przeprowadziłam dydaktyczne działanie interwencyjne, które za D. Klus-Stańską pojmuję jako „intencjonalną kreację warunków dydaktycznych, których nie można znaleźć w szkolnictwie powszechnym, po to, by móc obserwować procesy uczenia się w sytuacjach przez instytucje nieprzewidzianych i nieproponowanych" (Klus-Stańska, 2010: 131-132). W wyniku obserwacji uczestniczącej zebrałam materiał obejmujący czynności uczniów, a także skutki tych czynności (przede wszystkim plastyczne konkretyzacje - świadectwa odbioru tematyki egzystencjalnej wysnute z tekstów literackich oraz nagrania na taśmach audio i wideo znacznej części wypowiedzi dzieci (w wyniku transkrypcji sporządziłam około 400 fiszek z wypowiedziami dziecięcymi). 
Różnice w tekstowym obrazie świata podręczników i językowym obrazie świata w wypowiedziach dzieci, wyłoniły się szczególnie wyraźnie: w typach racjonalności, sposobach kategoryzacji pojęć, a także w stereotypowym i aksjologicznym oglądzie rzeczywistości. Obszary badań, powiązania między nimi oraz wewnętrzną złożoność obu dyskursów - dziecięcego i podręcznikowego - przedstawiam w zestawieniu tabelarycznym ${ }^{4}$.

Tabela 1. Typy racjonalności i sposoby kategoryzacji w tekstowym obrazie świata podręczników i językowym obrazie świata z perspektywy uczniów

\begin{tabular}{|c|}
\hline Kognitywistyczne kategorie badawcze: typy racjonalności i sposoby katege \\
\hline Tekstowy obraz świata podręczników \\
\hline $\begin{array}{l}\text { Świadomie zawęża się punkt widzenia do tego, co oczywiste: } \\
\text { — dominuje przekonanie o uporządkowaniu rzeczywistości: } \\
\text { „Nasze podwórko to miejsce, które najlepiej znamy. Wszyscy bez żadnych wyjątków, takie } \\
\text { podwórko mamy!... Czasami z naszego podwórka, na którym się na co dzień bawimy, widać } \\
\text { wieże kopalni lub wielkiej huty kominy”; } \\
\text { „Mróz na dworze i zawieje - kaloryfer dom nasz grzeje”; } \\
\text { „Na podwórku jest wesoło: domy wkoło, piaskownica - babkownica i aleje rowerowe, i dwie } \\
\text { bramki całkiem nowe”; } \\
\text { - ujawnia się silna tendencja do poetyzacji przyziemnej rzeczywistości: } \\
\text { „Dom gra! Trzeszczy podłogą i drzwiami, gra krokami na schodach, dom gra, gdy śpiewa radio } \\
\text { w pokoju lub kapie z kranu woda”. } \\
\text { „Pielęgniarka Maryla podobna jest do motyla i fruwa jak biały motyl tam i z powrotem, tam } \\
\text { i z powrotem. (...) Biegnie już biały motyl, przysiada na brzegu łóżka, odgarnia smutki jak } \\
\text { wróżka, i już zmartwienia znikają. Znów wszyscy się uśmiechają”. }\end{array}$ \\
\hline Językowy obraz świata z perspektywy uczniów \\
\hline $\begin{array}{l}\text { W zindywidualizowanym opowiadaniu świata przeważa: utylitaryzm, sensoryczność, antropo- } \\
\text { centryczny punkt widzenia: } \\
\text { „Strasznie się bałam pierwszego dnia w szkole; miałam lodowate i mokre ręce, nie mogłam nic } \\
\text { powiedzieć”; } \\
\text { "Ja pamiętam, jak pani czytała imiona nas wszystkich i ja wtedy wyszłam na środek, bo nie wie- } \\
\text { działam, że pani sprawdza tylko listę obecności. Ja myślałam, że pani coś ode mnie chce”; } \\
\text { „Kiedy pierwszy raz pani powiedziała do mnie: „Dzienniczek poproszę”, to ja myślałam, że mam } \\
\text { tylko pokazać dzienniczek”. }\end{array}$ \\
\hline
\end{tabular}

W podręcznikowym obrazie świata świadomie ogranicza się opis do językowo relewantnych cech wystarczających i koniecznych, zawężając punkt widzenia do tego, co oczywiste. Formuła opisu zamkniętego, oparta na zasadach racjonalizmu scjentystycznego, wyraża przekonanie o obiektywnym charakterze usystematy-

${ }^{4}$ Rozbieżności w tekstowym i językowym obrazie świata omawiam w skróconej wersji w tekście: Wiśniewska-Kin, 2013: 21-35. 
zowanego poznania i o uporządkowaniu rzeczywistości. Opis sprowadza się do analizy rzeczywistości pozajęzykowej, z wykluczeniem człowieka jako podmiotu interpretującego tę rzeczywistość.

W podręcznikowych strategiach porządkowania rzeczywistości ujawnia się silna tendencja do mitologizowania rzeczywistości, niewykraczania poza obszar oczywistości, upraszczania, problemów autentycznych, redukowania lub wręcz wykluczania obrazu złożonej rzeczywistości. Z doboru i układu profilów i faset wyłania się od początku do końca określony, gotowy obraz świata.

W przeciwieństwie do TOS-u podręczników, dziecięce sposoby objaśniania świata zakorzenione są w osobistym doświadczeniu, które rzutuje na sposoby pojmowania „przedmiotu mentalnego”. W zindywidualizowanym opowiadaniu świata dominuje utylitaryzm, sensoryczność, antropocentryczny punkt widzenia, myślenie „owinięte” wokół konkretu, poznawanie uwrażliwione na kontekst (przestrzenny i czasowy). Wielowymiarowy, zróżnicowany, niejednoznaczny dyskurs dziecięcy wykracza poza ustalone granice problemów, obrazuje inwencję, bogactwo oraz wrażliwość dzieci, ujawnia dziecięcą świadomość konfliktów i sprzeczności, uobecnia dziecięcą znajomość realiów i rozczarowanie rzeczywistością. Z doboru i układu profilów i faset wyłania się obraz trudnej, niejednoznacznej, skonfliktowanej, zmiennej rzeczywistości.

Tabela 2. Stereotypowy ogląd rzeczywistości w tekstowym obrazie świata podręczników i językowym obrazie świata z perspektywy uczniów

\begin{tabular}{|l|}
\hline \multicolumn{1}{|c|}{ Kognitywistyczne kategorie badawcze: stereotypowy ogląd rzeczywistości } \\
\hline \multicolumn{1}{|c|}{ Tekstowy obraz świata podręczników } \\
\hline Kreowaniu obrazu wzorcowego sprzyja \\
- mitologizowanie rzeczywistości: \\
„Mama i tata, mądre główki, są jak jabłka dwie połówki”; \\
„A mama wszystkim rozdaje uśmiechy jak pachnące jabłka, jak słodkie orzechy, jak mleko, \\
które rano pijemy co dnia”; \\
„U babci jest słodko, świat pachnie szarlotką”; \\
- upraszczanie problemów autentycznych: \\
„Jakie cudowne życie mają dzieci! Nie muszą chodzić do pracy, nie przejmują się tym, czy są \\
pieniądze na jedzenie, nie muszą sprzątać, gotować. W zasadzie... niczego nie muszą” \\
„Gdyby trosk ubyło mamie, jak myślicie, co się stanie? To codziennie, już od rana, w domu \\
będzie Super-Mama!”; \\
„A gdy czasem na kolegę spadnie kłopot albo bieda, no to wtedy nasza grupa smucić mu się \\
długo nie da”; \\
- redukowanie lub wręcz wykluczanie obrazu złożonej rzeczywistości: \\
„Dom otwiera swoje cztery ściany dla babci, dziadka, tatusia i mamy”; \\
„Pogładziłam i Izunię, i Danusię - jak to miło, że się troszczą o mamusię”;
\end{tabular}




\begin{tabular}{|l|}
\hline \multicolumn{1}{|c|}{ Językowy obraz świata } \\
\hline Zsubiektywizowane ujmowanie świata cechuje: \\
- świadomość konfliktów i sprzeczności: \\
„Są dobre domy albo wesołe, ale idealnego to chyba nie ma, bo nawet jak dzieci w miarę \\
dobrze się uczą, rodzice pracują i spotykają się z ciociami albo wujkami, to zawsze coś jest \\
nie tak. Albo pieniędzy nie starczy, albo na lekarstwo brakuje, a niektórzy przecież nie mają \\
codziennie obiadu. W każdym domu coś nie działa tak, jak powinno”; \\
- znajomość realiów i rozczarowanie rzeczywistością: \\
„Ja prawie wcale nie rozmawiam z rodzicami, bo ciągle ich nie ma w domu, a jak są to oglądają \\
telewizję, a ja gram u siebie w pokoju na komputerze”; \\
„Czasem, jak jestem smutna albo zła, to się chowam za stołem, bo tam nigdy nikt mnie nie \\
znajdzie, dopiero jak nie mogę tam już wytrzymać, to wyłażę. Zazwyczaj szuka mnie mój brat \\
Jasiek, bo rodzicom nie chce się mnie szukać”; \\
„Najgorsze w domu są poranki, bo wszystko trzeba robić szybko, szybko, a rano często nie \\
można skojarzyć, gdzie co jest, i w dodatku nie można o tym powiedzieć, trzeba wykonywać to, \\
co rodzice rozkażą, i nic się nie odzywać”.
\end{tabular}

Wyobrażenie obiektu „prawdziwego" w podręcznikach, nachylone jest w stronę obrazu wzorcowego. Obecność elementu idealizacji oraz myślenia postulatywnego czy życzeniowego, „mitologicznego", powoduje nakładanie na obraz tego, co jest, wyobrażenia tego, co być powinno.

Natomiast stereotypizacja dziecięca służy dzieciom do rozpoznawania obiektów otaczającej je rzeczywistości. W wypowiedziach, w których ujawnia się obraz przedmiotu typowego, skłaniają się one ku opisowości, informowaniu, kto jaki „jest naprawdę". Przez stosowanie powtarzalnych, ale i zmiennych „stereotypowych" cech semantycznych: relacyjnych, funkcjonalnych, percepcyjnych, dzieci utrwalają wyobrażenia związane $\mathrm{z}$ danym przedmiotem.

Sfera wartości narzuconych w podręczniku zamyka dzieci, odgradza je, odbiera im motywację do wysiłku towarzyszącego odkrywczości, niweczy szansę wzbogacania obrazu samego siebie dzięki satysfakcji płynącej z zajmowania się sprawami poważnymi i istotnymi, wyłączanie z zakresu zobowiązań szkoły znaczeń osobistych uczniów, powoduje wygaszanie w nich zaciekawienia światem. Odrealniony, zinfantylizowany i sielankowo-optymistyczny obraz pozbawia uczniów możliwości rozumienia zmiennej i chaotycznej współczesnej rzeczywistości.

Dyskurs dziecięcy zaś wyzwala myślenie o konieczności zaakceptowania otwartości poznawczej, która przyznaje uczniom prawo do wyrastania z egocentrycznego oglądu świata i poszerzania horyzontów własnej egzystencji o cele ogólne i wybiegające w przyszłość, poznawania siebie, rozumnego pielęgnowania indywidualności sprzężonej z empatią, odpowiedzialnością i troską o dobro ogólne, budowania własnej tożsamości w dialogu $\mathrm{z}$ innymi, przy poszanowaniu inności w zróżnicowanej kulturowo wspólnocie, roztropnego wykorzystywania czasu i przestrzeni oraz radzenia sobie z przeciwnościami losu. 
Tabela 3. Horyzonty aksjologiczne w tekstowym obrazie świata podręczników i językowym obrazie świata z perspektywy uczniów

\begin{tabular}{|l|}
\hline \multicolumn{1}{|c|}{ Kognitywistyczne kategorie badawcze: horyzonty aksjologiczne } \\
\hline \multicolumn{1}{|c|}{ Tekstobraz świata podręczników } \\
\hline Dominują wartości należące do sfer: \\
- poznawczo-intelektualnej oraz społecznej: \\
„Tak ładnie mówi nasza pani... O wszystkim wie! I wszystko zna! Gdy naszej pani my słuchamy, \\
to deszcz nie pada, a śpiewa, gra”; \\
„Pamiętaj, koleżanko, pamiętaj, kolego: jeden za wszystkich, wszyscy za jednego”; \\
„Gdy rano słońce zaświeci, wybiegają na dwór dzieci. Miotły, szczotki idą w ruch, bo dokoła \\
wielki brud. Żyć nie można w bałaganie, więc się bierzmy za sprzątanie”; \\
- osoby o odpowiednich predyspozycjach: \\
„Wszyscy mnie lubią to rzecz wspaniała, chyba się jednak dobrze starałam. Chciałam, by lubić \\
zaczą mnie ktoś, więc byłam miła, mówiłam wciąż: proszę, przepraszam, bardzo dziękuję \\
i uśmiechałam się, i w ogóle. Teraz mnie lubią wszyscy, więc w górę skaczę z radości - do \\
samych chmurek!”; \\
„Marudzenie precz do kąta! Od dziś dziecko samo sprząta! Zęby, uszy z chęcią myje! Nawet \\
szyję”; \\
„Przecież być miłym jest bardzo miło i wcale nie tak trudno”. \\
\hline \multicolumn{1}{|c|}{ Językowy obraz świata z perspektywy uczniów } \\
\hline Dziecięca konceptualizacja nazw wartości rozciąga się od wartości do antywartości: \\
- osoby i jej charakteru: \\
„Zawsze jak jestem sam, to się bardzo denerwuję i myślę, czy mama nie miała jakiegoś wypadku, \\
ale jak jestem z kimś, to zachowuję się normalnie, udaję, że nic się nie stało”; \\
„Ja wtedy ciągle patrzę w okno; sprawdzam, czy telefon działa; spoglądam na zegarek; podbiegam \\
do drzwi; siedzę w kącie; ja próbuję czytać, ale nie mogę się skupić”; \\
„Jak zrani cię przyjaciółka, to już nigdy nie będzie tak jak przedtem, już zawsze pamięta się o tej \\
zdradzie”; \\
Wartościowanie ujawnia się w metaforach orientacyjnych: \\
„Jak mam fajny dzień, to czuję się tak, jakbym unosiła się na skrzydłach”; \\
„Jak jest miłość w rodzinie to czuje się takie uczucie lekkości”. \\
\hline
\end{tabular}

Znaczące rozbieżności między dyskursem podręcznikowym a dziecięcym i przekonanie o możliwości poszerzenia przestrzeni semantycznej w dyskursie podręcznikowym przez wprowadzenie wątków pominiętych lub zmarginalizowanych upoważnia do sformułowania kilku wniosków i postulatów pod adresem praktyki edukacyjnej oraz pytań o możliwości uwzględnienia otwartości poznawczej w dyskursie edukacyjnym

Szczególnie ważne jest odinfantylizowanie edukacji wczesnoszkolnej i przełamanie schematycznej roli kształcenia zinstytucjonalizowanego przez poszerzenie przestrzeni semantycznej w podręcznikach o te wartości, które edukację czynią doświadczeniem istotnym i doniosłym w procesie stawania się pełnym człowiekiem. Warto więc zdążać do tego, by w dyskursie edukacyjnym stworzyło się miej- 
sce dla prawdziwie wzbogacających doświadczeń intelektualnych i duchowych, miejsce, w którym dzieci odkrywają, wykorzystują i rozwijają swój potencjał oraz znajdują satysfakcję w odkrywaniu prawd istotnych dla ich życia, a wyposażone w zdolność krytycznego myślenia, powiązaną z ciekawością poznawczą, potrafią wybrać między światem miałkich przyjemności i złudzeń a przywilejem twórczego używania własnego intelektu i czerpania z dziedzictwa kultury.

\section{Literatura}

Bernstein B. (1990). Odtwarzanie kultury. Przeł. Z. Bokszański, A. Piotrowski. Wrocław.

Chmielewski A., Dudzikowa M., Grobler A. (red.). (2012). Interdyscyplinarnie o interdyscyplinarności. Między ideą a praktyką. Kraków.

Czachur W., Kuczyńska A., Kumięga Ł. (2016). Jak analizować dyskurs? Perspektywy dydaktyczne. Kraków.

Dąbrowska E., Kubiński W. (red.). (2003). Akwizycja języka w świetle językoznawstwa kognitywnego. Kraków.

Erlauer L. (2003). The Brain Compatible Classroom. Alexandria, VA.

Grzymała-Kazłowska A. (2004). Socjologicznie zorientowana analiza dyskursu na tle współczesnych badań nad dyskursem. „Kultura i Społeczeństwo” 48 (1).

Gupta D.P., Richardson K. (2001). Children's Cognitive and Language Development. Oxford.

Horolets A. (red.). (2008). Analiza dyskursu w socjologii i dla socjologii. Toruń.

Klus-Stańska D. (2010). Dydaktyka wobec chaosu pojęć i zdarzeń. Warszawa.

Kowalski M.A. (2010). Dyskurs kolonialny w Drugiej Rzeczypospolitej. Warszawa.

Krauz M., Gajda S. (red.). (2005). Wspótczesne analizy dyskursu. Kognitywna analiza dyskursu a inne metody badawcze. Rzeszów.

Kurcz I., Bobryk J. (red). (2001). Psychologiczne studia nad jęzkiem i dyskursem. Warszawa.

Labocha J. (1996). Dyskurs jako proces przekazywania wiedzy. [W:] T. Rittel (red.), Dyskurs edukacyjny. Kraków.

Nocoń J. (2011). Stylistyczne aspekty dyskursu edukacyjnego. [W:] U. Sokólska (red.). Odmiany stylowe polszczyzny dawniej i dziś. Białystok.

Ostrowicka H. (2014). Kategoria dyskursu w języku i w badaniach edukacyjnych - w poszukiwaniu osobliwości pedagogicznie zorientowanej analizy dyskursu. „Forum Oświatowe” 2 (52).

Ożdżyński J. (red.). (1995). Językowy obraz świata dzieci i młodzieży. Kraków.

Pawliszek P., Rancew-Sikora D. (2012). Wprowadzenie do socjologicznej analizy dyskursu (SAD). „Studia Socjologiczne” 1 (204).

Przybyla O. (2004). Akty mowy w języku nauczycieli. Katowice.

Putkiewicz E. (2002). Proces komunikowania się na lekcji. Warszawa.

Rittel T. (1994a). Metodologia lingwistyki edukacyjnej. Rozwój języka. Kraków.

Rittel T. (1994b). Podstawy lingwistyki edukacyjnej. Nabywanie i kształcenie języka. Kraków.

Rittel T. (red.). (1996). Dyskurs edukacyjny. Kraków.

Shugar G.W. (1995). Dyskurs dziecięcy. Rozwój w ramach struktur społecznych. Warszawa. 
Skudrzyk A., Warchala J. (2002). Dyskurs edukacyjny a kompetencja interakcyjna. [W:] J. Porayski-Pomsta (red.). Czynności tworzenia i rozumienia wypowiedzi. „Studia Pragmalingwistyczne” t. 3. Sprenger M. (2003). Differentiation Through Learning Styles and Memory, Thousand Oaks.

Wierzchoń M., Orzechowski J., Barbasz J. (2012). Interdyscyplinarność w naukach kognitywnych science, fiction czy science fiction? [W:] A. Chmielewski, M. Dudzikowa, A. Grobler (red.). Interdyscyplinarnie o interdyscyplinarności. Między idea a praktyką. Kraków.

Wiśniewska H. (2005). Dyskurs edukacyjny jako neologizm w nauczaniu integrującym. [W:] E. Kozak-Czyżewska, D. Zyboł, B. Kępa (red.). Współczesne tendencje rozwoju pedagogiki wczesnoszkolnej. Kielce.

Wiśniewska-Kin M. (2013). Dominacja a wyzwolenie. Wczesnoszkolny dyskurs podręcznikowy i dziecięcy. Łódź.

Wodak R. (2011). Badania nad dyskursem - ważne pojęcia i terminy. [W:] R. Wodak, M. Krzyżanowski (red.). Jakościowa analiza dyskursu w naukach społecznych. Warszawa.

Wojtczuk K. (2002). Gra oficjalności i nieoficjalności językowej jako zasada organizacji dyskursu edukacyjnego. [W:] J. Porayski-Pomsta (red.). Czynności tworzenia i rozumienia wypowiedzi. „Studia Pragmalingwistyczne" t. 3. 